\title{
Herbage dry matter intake estimation of grazing dairy cows based on animal, behavioral, environmental, and feed variables
}

\author{
M. Rombach, ${ }^{1,2}$ K.-H. Südekum, ${ }^{2}$ A. Münger, ${ }^{1}$ and F. Schori ${ }^{1 *}$ \\ ${ }^{1}$ Agroscope, 1725 Posieux, Switzerland \\ ${ }^{2}$ University of Bonn, Institute of Animal Science, 53115 Bonn, Germany
}

\section{ABSTRACT}

Information about the individual herbage DMI (HDMI) of grazing dairy cows is important for an efficient use of pasture herbage as an animal feed with a range of benefits. Estimating HDMI, with its multifaceted influencing variables, is difficult but may be attempted using animal, performance, behavior, and feed variables. In our study, 2 types of approaches were explored: 1 for HDMI estimation under a global approach (GA), where all variables measured in the 4 underlying experiments were used for model development, and 1 for HDMI estimation in an approach without information about the amount of supplements fed in the barn (WSB). The accuracy of these models was assessed. The underlying data set was developed from 4 experiments with 52 GA and 50 WSB variables and one hundred thirty 7 -d measurements. The experiments differed in pasture size, herbage allowance, pregrazing herbage mass, supplements fed in the barn, and sward composition. In all the experiments, cow behavioral characteristics were recorded using the RumiWatch system (Itin and Hoch GmbH, Liestal, Switzerland). Herbage intake was estimated by applying the n-alkane method. Finally, HDMI estimation models with a minimal relative prediction error of $11.1 \%$ for use under GA and $13.2 \%$ for use under WSB were developed. The variables retained for the GA model with the highest accuracy, determined through various selection steps, were herbage crude protein, chopped whole-plant corn silage intake in the barn, protein supplement or concentrate intake in the barn, body weight, milk yield, milk protein, milk lactose, lactation number, postgrazing herbage mass, and bite rate performed at pasture. Instead of the omitted amounts of feed intake in the barn and, due to the statistical procedure for model reduction, the unconsidered variables postgrazing herbage mass and bite rate performed at pasture, the WSB model with

Received March 27, 2018.

Accepted November 27, 2018.

*Corresponding author: fredy.schori@agroscope.admin.ch the highest accuracy retained additional variables. The additional variables were total eating chews performed at pasture and in the barn, total eating time performed at pasture, number of total prehension bites, number of prehension bites performed at pasture, and herbage ash concentration. Even though behavioral characteristics alone did not allow a sufficiently accurate individual HDMI estimation, their inclusion under WSB improved estimation accuracy and represented the most valid variables for the HDMI estimation under WSB. Under GA, the inclusion of behavioral characteristics in the HDMI estimation models did not reduce the root mean squared prediction error. Finally, further adaptation, as well as validation on a more comprehensive data set and the inclusion of variables excluded in this study such as body condition score or gestation, should be considered in the development of HDMI estimation models.

Key words: dairy cow, herbage intake estimation, mastication, pasture, prehension

\section{INTRODUCTION}

In addition to a better consumer image (Getter et al., 2015), improved animal welfare (Arnott et al., 2017), and higher product quality (O'Callaghan et al., 2016), grazing dairy cows offer potential ecological (Guyader et al., 2016) and economic (Holshof et al., 2015) benefits. However, recent estimates have shown that only 49 to $52 \%$ of lactating dairy cows in European countries have access to pasture, and the numbers have been declining in recent years (Van den Pol et al., 2015). Although pasture herbage has widely been identified as the cheapest source of nutrients for dairy cows (Peyraud et al., 2001), the decline in grazing may be the result of larger herds, fragmentation or lack of land, development of automatic milking systems, and farmer expectations regarding productivity in a pasture-based system, as mentioned by Kristensen et al. (2010). Information about individual herbage DMI (HDMI) allows estimating the nutrient supply from pastures and determining an adapted optional supplementation in the barn that may improve efficiency and lead to higher 
acceptance in practice. Furthermore, information about intake compared with production can be used to assess the nutrient and energy efficiency of individual grazing dairy cows and may enable selection for this trait. Several methods for HDMI estimation exist. These include measuring herbage mass or sward surface height before and after grazing, back calculation from the energy requirements of the cows and the energy density of the offered herbage, near-infrared reflectance spectroscopy, and marker techniques (Decruyenaere et al., 2009). However, these techniques are expensive, time consuming, and impracticable at the farm level and yield only group- or herd-mean HDMI estimations. Behavioral characteristics may also be considered in estimating the individual animal HDMI (Andriamandroso et al., 2016). Oudshoorn et al. (2013) calculated grass intake using regressions based on grazing time and animal individual bite frequency. Various methods based on jaw switches, pressure sensors, microphones, accelerometers, and electromyography have been developed to record behavioral characteristics automatically. Among these, pressure sensors and microphones can detect jaw movements with high accuracy (Andriamandroso et al., 2016). Because the RumiWatch system (RWS; Itin and Hoch GmbH, Liestal, Switzerland), based on a pressure sensor and a triaxial accelerometer, showed reliable accuracy in detecting eating and rumination behavior (Ruuska et al., 2016; Rombach et al., 2018), it was chosen for the present investigation. However, eating chews or prehension bites alone seem insufficient to estimate HDMI, and they explain only a minor part of HDMI variation. Therefore, in addition to behavioral characteristics, Decruyenaere et al. (2009) mentioned animal and feed characteristics that might have an influence on the HDMI of grazing ruminants. Timmer et al. (2016) showed a reliable estimation of HDMI using behavioral as well as animal- and herbage-related variables in the HDMI estimation model. In our study, we built models for HDMI estimation based on 2 approaches using the RWS, which can differentiate between mastication chews and prehension bites. Data from 4 experiments were used. The data contained differences in farm management, pasture size, grazing duration, herbage allowance, pregrazing herbage mass, supplements fed in the barn, and sward composition. The main objective of our study was to develop models for HDMI estimation based on the merged data set of the 4 experiments mentioned above. First, a global approach (GA) was explored, where all measured variables were used for the model development. Then, a second approach was investigated without the information about the supplemented amounts of forage or concentrate in the barn (referred to as WSB). Finally, we studied the effect of behavioral characteristics recorded with the RWS on the accuracy of the HDMI estimation under both approaches.

\section{MATERIALS AND METHODS}

\section{Experimental Design, Animals, and Housing}

Three grazing experiments were conducted at the Agroscope experimental farm in Posieux, Switzerland, and 1 was conducted at the Ferme-Ecole in Sorens, Switzerland, from 2014 to 2016 (Table 1). All experimental procedures were in accordance with Swiss guidelines for animal welfare and were approved by the Animal Care Committee of the Canton Fribourg, Switzerland (no. 2014_38_FR, 2014_51_FR, 2015_11_FR, and 2015_22_FR). Before selection of the experimental cows, all cows passed a medical check. In general, each period consisted of 2 wk of adaptation to adjust pasture-accustomed cows to the various feeding treatments and measuring devices followed by 1 wk of data collection. Consequently, the experiments lasted 21 to 63 d. Between 18 and 28 Holstein and Red Holstein cows were used in the experiments. The experimental cows were distributed equally across the experimental groups based on BW, milk yield, DIM, and lactation number. At the beginning of the experiments, the cows had an average BW of $601 \pm 58.7 \mathrm{~kg}$, were $155 \pm 64.5$ DIM, were in lactation $2.5 \pm 1.75$ on average, and produced $24.2 \pm 5.18 \mathrm{~kg}$ of milk/d $( \pm \mathrm{SD})$.

In all 4 experiments, the paddocks were grazed rotationally, and the stocking periods lasted 1 to $3 \mathrm{~d}$. All cows grazed day and night between 16 and $19 \mathrm{~h} / \mathrm{d}$ depending on the experiment. In the meantime, the cows were kept in freestall barns and were supplemented if intended as part of the treatment structure. In addition, they were milked, milk was sampled, and alkane marker capsules were administered. On average, the pastures (permanent and sown) comprised grasses (mainly Lolium perenne, Poa pratensis, and Lolium multiflorum; $58-84 \%$ of the fresh herbage biomass), legumes (Trifolium repens and Trifolium pratense; $6-26 \%$ of the fresh herbage biomass), and forbs (mainly Taraxacum officinale, Plantago lanceolata, and Rumex acetosa; $2-29 \%$ of the fresh herbage biomass).

The first experiment (EX1) was organized as a crossover block design with 3 treatments and 3 periods (Table 1). All experimental cows in EX1 grazed as a single group in the same paddocks. Two out of 3 experimental groups were supplemented in the barn at weighing troughs (Insentec B.V., Marknesse, the Netherlands) with either $10 \mathrm{~kg} \mathrm{DM} / \mathrm{d}$ of chopped wholeplant corn silage or with $8.2 \mathrm{~kg} \mathrm{DM} / \mathrm{d}$ of chopped whole-plant corn silage mixed with $1.8 \mathrm{~kg} \mathrm{DM} / \mathrm{d}$ of protein concentrate (60\% expeller soybean meal, $25 \%$ 


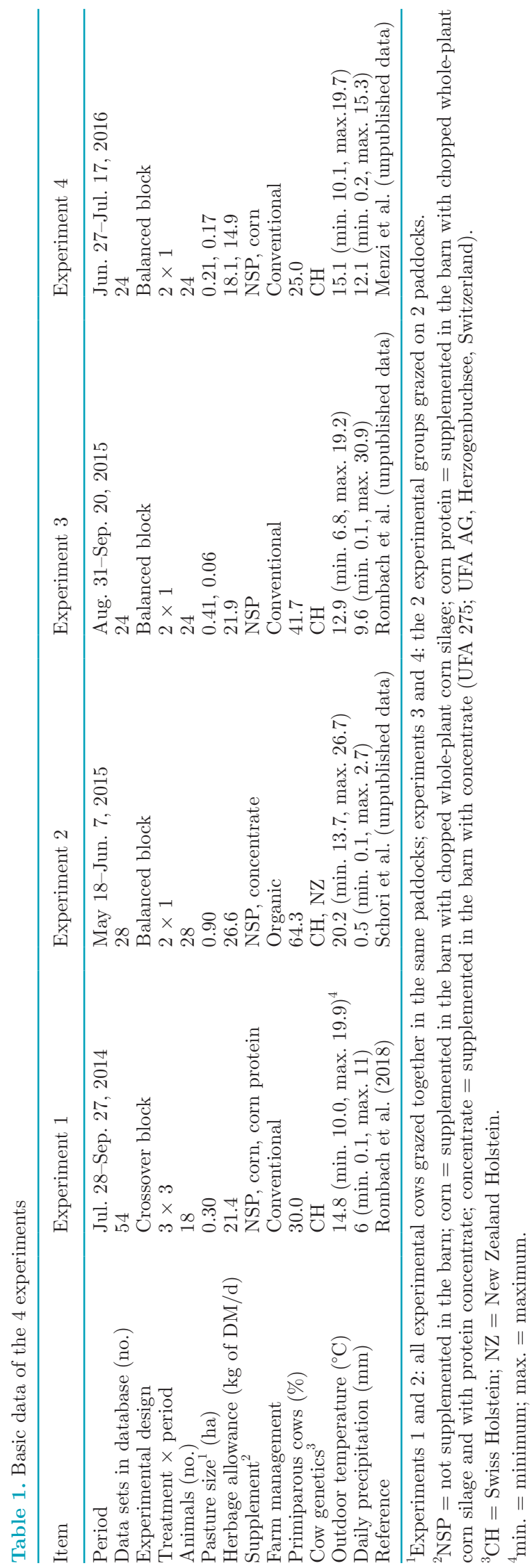

corn gluten, $10 \%$ potato protein, and $5 \%$ dried sugar beet pulp). The third group was not supplemented. Each cow served as its own control and underwent all 3 treatments. The second (EX2), third (EX3), and fourth (EX4) experiments were performed as balanced block designs including 2 treatments and 1 period. In EX2, 1 group was supplemented with an average of $3 \mathrm{~kg} \mathrm{DM} / \mathrm{d}$ of concentrate (UFA 275; UFA AG, Herzogenbuchsee, Switzerland) through an automatic concentrate feeder in the barn. The other group received no concentrate. All experimental cows in EX2 grazed as a single group in the same paddocks. In EX3, one group of cows grazed on swards with a high herbage mass of 2,288 $\mathrm{kg}$ of DM/ha, and the other group grazed on swards with a low herbage mass of $589 \mathrm{~kg}$ of DM/ ha. The cows in both groups had a similar herbage allowance of approximately $22 \mathrm{~kg}$ of DM/d per cow and were not supplemented in the barn. In EX3 and EX4, the cows from each group grazed on different paddocks. One experimental group in EX4 was supplemented in the barn at the weighing troughs (Insentec B.V.) with $4 \mathrm{~kg} \mathrm{DM} / \mathrm{d}$ of chopped whole-plant corn silage. The other group received no supplementation. The chemical composition of the herbage and the supplements fed during the experimental periods are shown in Tables 2 and 3. The cows had free access to drinking water during all experiments. The ambient outdoor temperature and the amount of rainfall during the experiments were recorded daily at the meteorological station in Grangeneuve (Meteo-Schweiz, Station Posieux, Switzerland).

\section{Data Recording and Sample Collection}

The sward height was measured daily in all experiments using an electronic rising plate meter (Jenquip, Feilding, New Zealand; 1 click unit $=0.5 \mathrm{~cm}$; EX1, EX3, and EX4) or a C-Dax Pasture Meter (C-Dax Ltd., Palmerston North, New Zealand; EX2). Herbage mass was measured before and after grazing each paddock by cutting 2 strips $(1 \mathrm{~m}$ wide $\times 9.4 \pm 3.02(\mathrm{SD}) \mathrm{m}$ long; $>6.7$ click units or 3.35 -cm stubble height) with a sickle-bar mower (Rekord 38, Bucher Landtechnik AG, Niederweningen, Switzerland). The herbage mass of the cut strips and the analyzed herbage DM content were used to calculate the herbage mass.

The RWS, consisting of the RumiWatch Halter (RWH; Itin and Hoch GmbH) and the RumiWatch Converter 0.7.3.31 (Itin and Hoch $\mathrm{GmbH}$ ), was used in all experiments to record and evaluate the behavioral characteristics of the experimental cows. Further details about the RWS, the accuracy and definition of the recorded behavioral characteristics, and the setup and handling of the RWH have been described previously (Rombach et al., 2018). To accustom the cows to the 
ROMBACH ET AL.

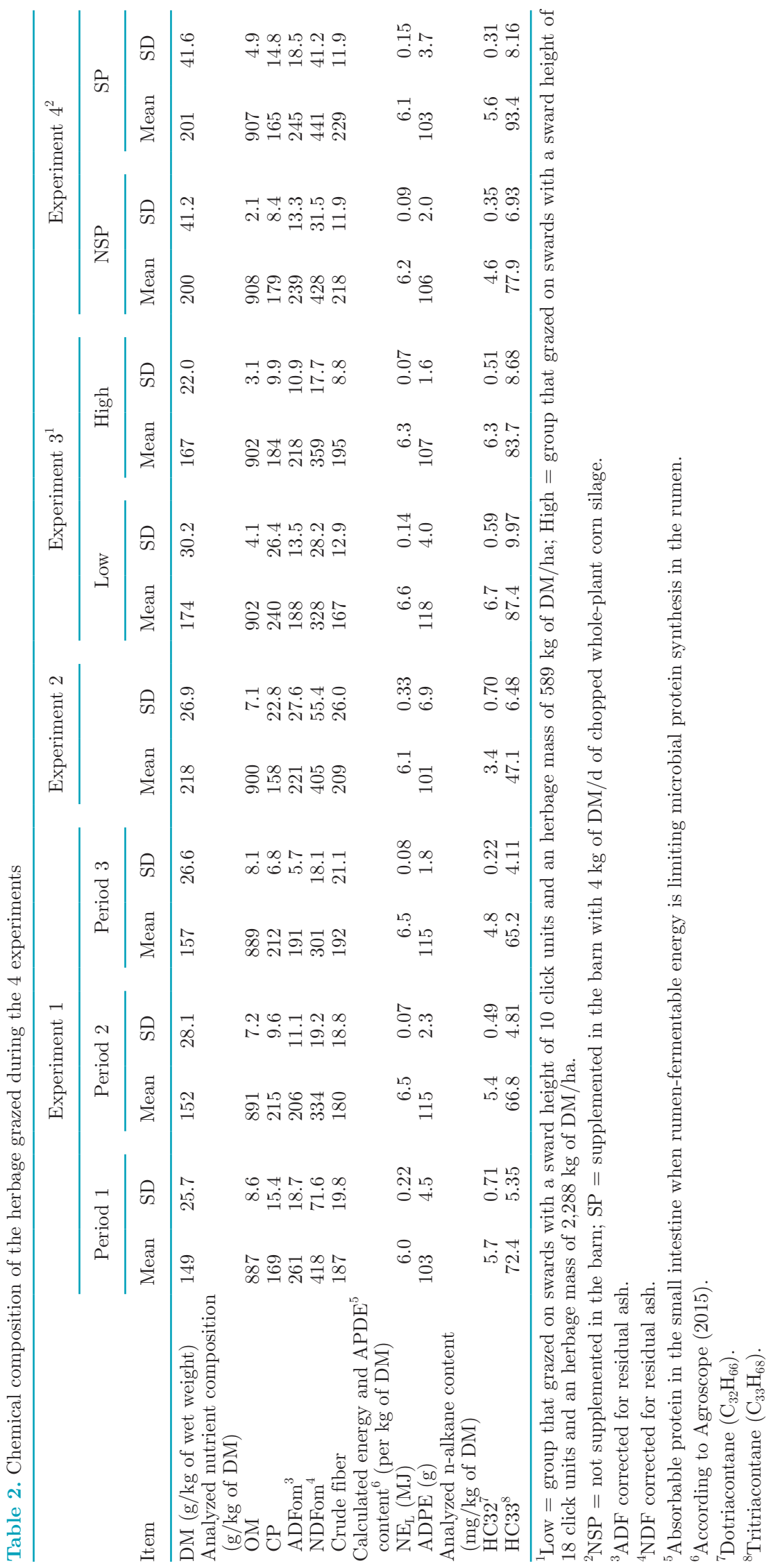


Table 3. Average chemical composition of the supplements fed during the experiments

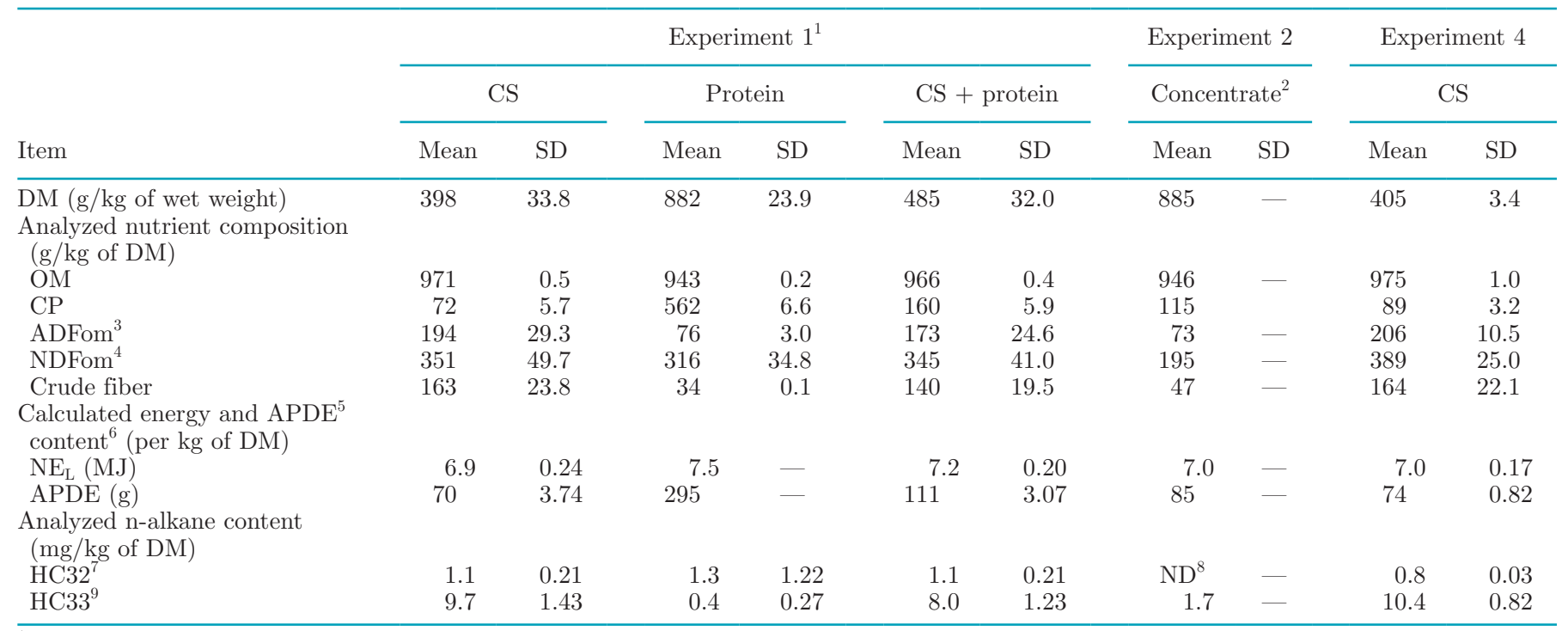

${ }^{1} \mathrm{CS}=$ chopped whole-plant corn silage; Protein = protein concentrate consisting of (as-fed basis) $60 \%$ expeller soybean meal, $25 \%$ corn gluten, $10 \%$ potato protein, and $5 \%$ dried sugar beet pulp.

${ }^{2}$ Commercial concentrate (UFA 275; UFA AG, Herzogenbuchsee, Switzerland).

${ }^{3} \mathrm{ADF}$ corrected for residual ash.

${ }^{4} \mathrm{NDF}$ corrected for residual ash.

${ }^{5}$ Absorbable protein in the small intestine when rumen-fermentable energy is limiting microbial protein synthesis in the rumen.

${ }^{6}$ According to Agroscope (2015).

${ }^{7}$ Dotriacontane $\left(\mathrm{C}_{32} \mathrm{H}_{66}\right)$.

${ }^{8}$ Not detected.

${ }^{9}$ Tritriacontane $\left(\mathrm{C}_{33} \mathrm{H}_{68}\right)$.

measuring system, the RWH were attached to the cows $4 \mathrm{~d}$ before the start of each measuring week and left on throughout the week. In EX1, 15 cows were equipped with version 3.0 of the RWH and 3 cows were equipped with version 6.0. These differ in materials, adjustability, and wearing comfort. In EX2, EX3, and EX4, all cows were equipped with RWH version 6.0. The recorded raw data were read through the interface software RumiWatch Manager (version 2.1.0.0; Itin and Hoch $\mathrm{GmbH}$ ) and processed using the evaluation software RumiWatch Converter (version 0.7.3.31). Compared with the converters used in Rombach et al. (2018), RumiWatch Converter 0.7.3.31 allows a differentiation of other bites, mastication chews with the head up, mastication chews with the head down, prehension bites, and time spent masticating and eating.

Milk yield was measured twice daily during the milkings in the milking parlor (EX1, EX3, EX4: Fullwood, Arnold Bertschy AG, Guschelmuth, Switzerland; EX2: MidiLine, DeLaval AG, Sursee, Switzerland) with a Pulsameter (EX1, EX3, EX4: LMS GmbH Stützerbach, Ilmenau, Germany) or an MM15 (EX2: DeLaval AG). Milk composition was measured for EX1, EX2, and EX4 on d 2 and 5 and for EX3 on d 2, 4, and 6 during the measuring week. Aliquots of subsamples from the morning and evening milkings were pooled and preserved in 1 sample tube containing a Broad-Spectrum Microtab II (Gerber Instruments AG, Effretikon, Switzerland) and stored at $8^{\circ} \mathrm{C}$ for subsequent analysis of milk fat, protein, lactose, and casein content. After each milking, BW was measured with an animal weighing system (EX1, EX3, EX4: Ga5010, Insentec B.V.; EX2: W-2000, DeLaval AG).

Individual HDMI was estimated using the n-alkane double indicator method (Mayes et al., 1986). Six days before each measuring week until the next-to-last day of the measuring weeks, cows were dosed twice daily with 1 gelatine capsule (HGK-17-60 sl; Capsula GmbH, Ratingen, Germany) containing $0.5 \mathrm{~g}$ of dotriacontane $\left(\mathrm{C}_{32} \mathrm{H}_{66}\right.$, HC32; Minakem Beuvry Production S.A.S., Beuvry la Forêt, France) as the external alkane marker on a carrier of $4.5 \mathrm{~g}$ of dried fruit pomace. During $7 \mathrm{~d}$, once per day after the morning milking, feces of each cow were spot-sampled indoors to determine the content of alkanes in the feces. Samples were taken from spontaneous defecations or with mild stimuli, pooled for each cow and measuring week, and stored at $-20^{\circ} \mathrm{C}$ for further analysis. To determine the content of al- 
kanes in the herbage eaten by the cows, herbage collection was carried out $7 \mathrm{~d}$, in the morning and afternoon. By following the experimental cows one after another and observing their grazing selection, small samples of the most likely grazed herbage were cut with a battery grass shearer (Gardena; Husqvarna Schweiz AG, Mägenwil, Switzerland). The herbage sampling started $24 \mathrm{~h}$ before the feces sampling and ended $24 \mathrm{~h}$ earlier. These samples were chopped and stored at $-20^{\circ} \mathrm{C}$ for further analysis.

\section{Laboratory Analysis}

Milk samples were analyzed using Fourier-transform mid-infrared spectrometry (Combi-Foss FT +; Foss, Hillerød, Denmark) to determine fat, protein, casein, and lactose content. Fluorescence flow cytometry (Fossomatic FC200; Foss) was used to count the number of somatic cells in the milk samples.

The herbage and supplement samples, except the protein supplement in EX1 and concentrate supplement in $\mathrm{EX} 2$, were stored at $-20^{\circ} \mathrm{C}$ until they were lyophilized (Delta 1-24 LSC; Christ, Osterode, Germany). Subsequently, all samples, including protein and concentrate supplements, were milled through a 1.0-mm screen (Brabender mill with titanium blades; Brabender GmbH \& Co. KG, Duisburg, Germany), dried for $3 \mathrm{~h}$ at $105^{\circ} \mathrm{C}$ to determine $\mathrm{DM}$, and finally incinerated at $550^{\circ} \mathrm{C}$ until a stable mass was reached to determine the ash content (AOAC International, 1995; method 942.05). Mineral residues in the ash were dissolved by nitric acid and analyzed for $\mathrm{Ca}, \mathrm{P}, \mathrm{Na}, \mathrm{Mg}$, and $\mathrm{K}$ with inductively coupled plasma optical emission spectrometry (ICPOES Optima 7300 DV; PerkinElmer, Waltham, MA) based on ISO (2009; method 27085). The contents of the HC32 and tritriacontane $\left(\mathrm{C}_{33} \mathrm{H}_{68}\right)$ were analyzed as described by Thanner et al. (2014). The N content of herbage and supplement samples was analyzed using the Dumas method (ISO, 2008; method 16634-1) on a $\mathrm{C} / \mathrm{N}$ analyzer (Trumac CNS; Leco Instruments, St. Joseph, MI); the results were multiplied by 6.25 to obtain the CP content. The contents of ADF (AOAC International, 1995; method 973.18), NDF (AOAC International, 1995; method 2002.4), and crude fiber (AOAC International, 1995; method 978.10) for the herbage and supplement samples were analyzed with Gerhardt Fibertherm (Gerhardt GmbH \& Co. KG, Königswinter, Germany). The NDF and ADF contents were separately determined (parallel). For NDF analysis, heat-stable amylase and sodium sulfite were added. A correction for the residual ash obtained after $2 \mathrm{~h}$ of incineration at $550^{\circ} \mathrm{C}$ was made for $\mathrm{ADF}$ corrected for residual ash and NDF corrected for residual ash.

\section{Calculations and Data Analysis}

The $\mathrm{NE}_{\mathrm{L}}$ content of herbage was calculated from chemical composition according to Agroscope (2015). For chopped whole-plant corn silage, $\mathrm{NE}_{\mathrm{L}}$ content was calculated according to Agroscope (2006). Herbage intake calculation was based on equations proposed by Mayes et al. (1986). Equation 1 was used to calculate the daily HDMI of every single experimental cow in the 4 experiments:

$$
\begin{aligned}
& \mathrm{HDMI}= \\
& \frac{\frac{F_{33}}{F_{32}} \times\left\{\begin{array}{l}
{\left[A_{32}+\left(P \times P_{32}\right)+\left(C N \times C N_{32}\right)+\left(C R \times C R_{32}\right)\right.} \\
-\left(P \times P_{33}+C N \times C N_{33}+C R \times C R_{33}\right)
\end{array}\right\}}{H_{33}-\frac{F_{33}}{F_{32}} \times H_{32}},
\end{aligned}
$$

where HDMI represents the daily HDMI $(\mathrm{kg}) ; F_{33}$, $H_{33}, P_{33}, C N_{33}$, and $C_{33}$ are the concentrations of tritriacontane $(\mathrm{mg} / \mathrm{kg}$ of $\mathrm{DM})$ in feces, herbage, protein supplement, concentrate, and chopped whole-plant corn silage, respectively; $F_{32}, H_{32}, P_{32}, C N_{32}$, and $C R_{32}$ are the concentrations of HC32 $(\mathrm{mg} / \mathrm{kg}$ of DM) in feces, herbage, protein supplement, concentrate, and chopped whole-plant corn silage consumed, respectively; $P, C N$, and $C R$ are the amounts $(\mathrm{kg}$ of $\mathrm{DM} / \mathrm{d})$ of consumed protein supplement, concentrate, and chopped wholeplant corn silage, respectively; and $A_{32}$ is the daily dose of HC32 (mg/d) administered via the alkane capsules.

The weekly averages of pasture, herbage, intake, animal, milk, and behavioral data used for the development of the different HDMI estimation models are shown in Table 4. The HDMI estimated by the n-alkane double indicator method was used as the reference herbage intake on pasture for the development and validation of 4 approaches. First, a GA was explored, where all variables in the data set were used for the model development. Afterward, a WSB approach was investigated without information about the amount of the supplements fed in the barn; the variables whole-plant corn silage, protein supplement, and concentrate intake were removed from the data set for the model development. Finally, to study the benefits of behavioral characteristics as predictors for HDMI estimation, the behavioral characteristics recorded with the RWS were removed from the data set of the GA and the WSB. These approaches without RWS variables are hereafter referred to as GAwRW and WSBwRW, respectively.

Univariate and bivariate graphics and descriptive statistics were used to provide an overview of the data set. Linear dependencies between regression variables 
Table 4. Mean $(\mathrm{n}=109)$ and range of the pasture, intake, animal, milk, and behavioral characteristics used for the herbage DMI estimation models

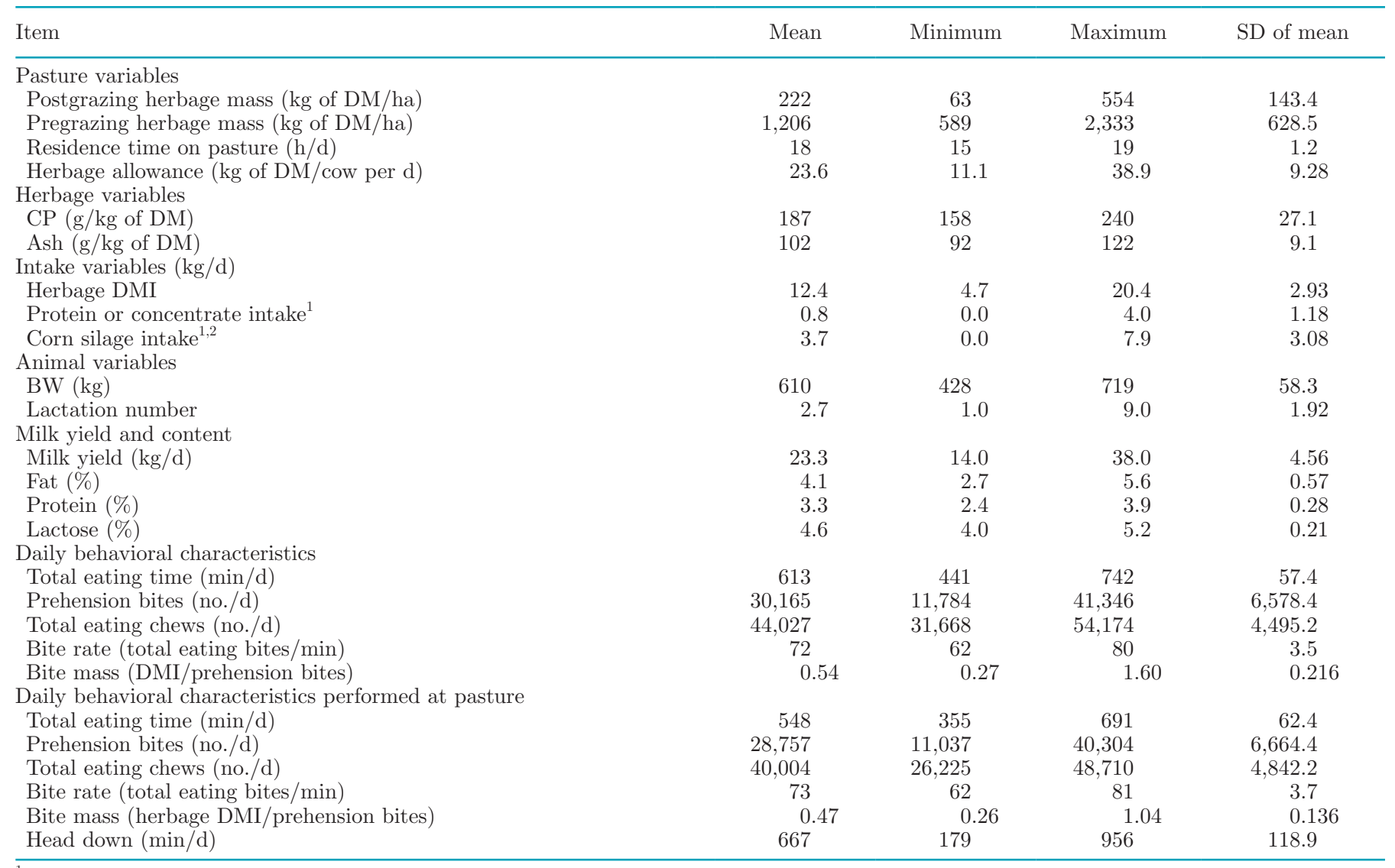

${ }^{1}$ Consumed in the barn.

${ }^{2}$ Chopped whole-plant corn silage.

were detected by Pearson correlation coefficients near or equal to 1 and prevented by the exclusion of redundant variables.

A preliminary set of predictive linear models was based on the combined results of various statistical approaches (principal component analysis; partial least squares; forward, backward, and sequential selection; and best subset regression) using Systat 13 (version 13.0; Systat Software, Chicago, IL) and R (R Core Team, 2016) packages Rcmdr (Fox, 2005, 2017; Fox and Bouchet-Valat, 2017), leaps (Lumley and Miller, 2017), and rms (Harrell, 2017).

Spearman correlation coefficients facilitated the identification of monotonous relations between the reference variable (HDMI) and the continuous or ordinal regressors. Principal component analysis using the Pearson and Spearman correlation matrices, partial least squares regression (including dummy variables for categorical factors), linear models (forward, backward, and sequential selection), canonical correlation, and finally best subset regression modeling was applied to identify variables that (from a statistical point of view) could be deleted from the set of regressors, leaving a list of potentially important predictor variables. The complete set of variables as well as the statistical findings were assessed, and variables were included or excluded based on the statistical findings, pertinent knowledge, and experience. The resulting combined set of 25 variables was still too large. Therefore, model reduction by the best subset regression approach was applied, and models with fewer than 14 variables were kept for the final validation. As the sample size was too small to keep an independent validation set, the bootstrap validation method proposed by Harrell (2015) and implemented in the $\mathrm{R}$ function rms:validate .ols (Harrell, 2017) was used. This function combines modeling, model reduction, and bootstrap validation. The root mean squared prediction error (RMSPE) calculation was based on the results of 5,000 bootstrap samples (Efron and Hastie, 2016) to identify the optimal predictive model while still preventing overfitting. Moreover, the bootstrap validation method was 
Table 5. Evaluated linear model GA7 for herbage DMI estimation for use under a global approach

\begin{tabular}{|c|c|c|c|c|c|c|}
\hline Item & Coefficient & $\mathrm{SE}$ & $\beta^{1}$ & \multicolumn{2}{|c|}{$95 \% \mathrm{CI}$} & $P$-value \\
\hline Model mean $\mu$ & 11.27 & 6.182 & 0 & -0.9954 & 23.5393 & 0.071 \\
\hline Corn silage intake $(\mathrm{kg}$ of $\mathrm{DM} / \mathrm{d})$ & -0.64 & 0.047 & -0.646 & -0.7369 & -0.5497 & $<0.001$ \\
\hline Milk lactose (\%) & -2.52 & 0.740 & -0.187 & -3.9876 & -1.0497 & $<0.001$ \\
\hline Lactation number & -0.29 & 0.091 & -0.191 & -0.46686 & -0.1055 & 0.002 \\
\hline BW (kg) & 0.008 & 0.0034 & 0.170 & 0.0012 & 0.0148 & 0.021 \\
\hline Milk protein (\%) & 4.24 & 0.595 & 0.410 & 3.0599 & 5.4208 & $<0.001$ \\
\hline Milk yield (kg/d) & 0.35 & 0.037 & 0.570 & 0.2786 & 0.4272 & $<0.001$ \\
\hline
\end{tabular}

${ }^{1}$ Standardized coefficient; helps classify the variables according to their effect on the corresponding herbage DMI estimation model.

${ }^{2}$ Performed at pasture.

enhanced by including the optimism bias to prevent an underestimation of the RMSPE. Equation 2 shows the multiple linear regression structure of the HDMI estimation models:

$$
\begin{gathered}
y=\mu+(V 1 \times C 1)+(V 2 \times C 2)+\ldots . \\
+(V n \times C n),
\end{gathered}
$$

where $y$ represents the average daily HDMI $(\mathrm{kg} / \mathrm{cow})$ over $1 \mathrm{wk} ; \mu$ is the model mean; and $V 1, V 2, \ldots ., V n$ are the explanatory variables with the corresponding coefficients $C 1, C 2, \ldots, C n$.

\section{RESULTS}

A data set of 130 measurements taken over $7 \mathrm{~d}$ consisting of 52 variables for GA and 50 variables for WSB (without protein supplement or concentrate and chopped whole-plant corn silage intake) was the database for the development and validation of the HDMI estimation models. For the development and validation of the WSBwRW and GAwRW HDMI estimation models, the data sets consisted of 42 variables for GAwRW (without 10 behavioral characteristics) and 40 variables for WSBwRW (without 10 behavioral characteristics and without protein supplement or concentrate and chopped whole-plant corn silage intake), and 130 measurements taken over $7 \mathrm{~d}$ were used. Due to technical difficulties with the RWH, in particular liquid leakage in the pressure sensor tubes, $21(16 \%)$ of the records could not be correctly evaluated over the whole measuring week and were therefore not used for further model development and validation if behavioral characteristics were used in the HDMI estimation models. Thus, the final data set for GA and WSB model development consisted of 109 measurements.

\section{HDMI Estimation Under a GA}

The model with the lowest RMSPE for HDMI estimation under GA without overfitting (eliminating the nonsignificant variables) was model GA7 (Table 5). In this model, according to the $\beta$ value (used to classify the variables and their effect on the HDMI estimation models), intake of chopped whole-plant corn silage $[P$ $<0.001$; standardized coefficient $(\beta)=-0.646]$ showed the greatest effect on the target variable (HDMI), followed by milk yield $(P<0.001, \beta=0.570)$, milk protein content $(P<0.001, \beta=0.410)$, intake of protein supplement or concentrate $(P<0.001, \beta=-0.393)$, herbage CP $(P<0.001, \beta=-0.265)$, lactation number $(P=0.002, \beta=-0.191)$, milk lactose content $(P<$ $0.001, \beta=-0.187)$, postgrazing herbage mass $(P<$ $0.001, \beta=-0.180)$, BW $(P=0.021, \beta=0.170)$, and bite rate performed at pasture $(P=0.046, \beta=-0.101)$.

\section{HDMI Estimation Model Under an Approach Without Knowledge of the Supplements Fed}

The model with the lowest RMSPE for HDMI estimation under WSB without overfitting (eliminating the nonsignificant variables) was model WSB8 (Table $6)$. In this model, according to the $\beta$ value, number of prehension bites performed at pasture $(P<0.001, \beta=$ 2.475 ) showed the greatest effect on HDMI, followed by number of prehension bites $(P=0.002, \beta=-1.994)$, total time spent eating on pasture $(P<0.001, \beta=$ $0.636)$, number of total eating chews $(P<0.001, \beta$ $=-0.488)$, BW $(P=0.001, \beta=0.265)$, milk lactose content $(P<0.001, \beta=-0.236)$, herbage ash $(P=$ $0.004, \beta=0.236)$, milk yield $(P=0.004, \beta=0.216)$, herbage $\mathrm{CP}(P=0.003, \beta=-0.209)$, lactation number $(P=0.011, \beta=-0.199)$, and milk protein content $(P$ $=0.014, \beta=0.172$ ). 


\section{Validation of the HDMI Estimation Models}

The models suggested for GA (GA1-GA7) showed an estimation accuracy $[100 \%$ - relative prediction error (RPE)] of $86.9 \%$ (GA1), increasing by an average of $0.3 \%$ for every variable added to $88.9 \%$ for model GA7. Model GA7 explained $79 \%$ of the HDMI variation, with an RMSPE of $1.38 \mathrm{~kg}$ of DM/animal per day and an RPE of $11.1 \%$ (Table 7).

The models suggested for WSB (WSB1-WSB8) showed an estimation accuracy of $85.1 \%$ (WSB1), increasing by an average of $0.2 \%$ for every variable added to $86.8 \%$ for model WSB8. Furthermore, model WSB8 explained $70 \%$ of the HDMI variation, with an RMSPE of $1.64 \mathrm{~kg}$ of DM/animal per day and an RPE of $13.2 \%$ (Table 7).

The models suggested for GAwRW (GAwRW1GAwRW7; detailed data not shown) showed an estimation accuracy of $86.9 \%$ (GAwRW1), increasing by an average of $0.2 \%$ for every variable added to $88.3 \%$ for model GAwRW7. Furthermore, the model for GAwRW7 explained $77 \%$ of the HDMI variation, with an RMSPE of $1.5 \mathrm{~kg}$ of DM/animal per day and an RPE of $11.7 \%$.

The models suggested for the approaches without behavioral characteristics (WSBwRW1-WSBwRW8; detailed data not shown) exhibited an estimation accuracy of $81.9 \%$ (WSBwRW1), decreasing by an average of $0.03 \%$ for every variable added to $81.7 \%$ for model WSBwRW8. Furthermore, the model WSBwRW8 explained $45 \%$ of the HDMI variation, with an RMSPE of $2.3 \mathrm{~kg}$ of DM/animal per day and an RPE of $18.3 \%$.

Figure 1 presents the RMSPE of the HDMI estimation models with and without behavioral characteristics (RWS variables). Models without information about supplementation and behavioral characteristics exhibit an RMSPE between 2.2 and $2.3 \mathrm{~kg}$ of $\mathrm{DM} /$ animal per day depending on the number of predictors in the model. Inclusion of behavioral characteristics reduced the error term by about $0.5 \mathrm{~kg}$ of $\mathrm{DM} /$ animal per day. If amounts of supplements fed in the barn were available for HDMI estimation, the error term decreased again about $0.3 \mathrm{~kg}$ of $\mathrm{DM} /$ animal per day to end at 1.3 to $1.6 \mathrm{~kg}$ of $\mathrm{DM} /$ animal per day. In this case, inclusion of behavioral information did not additionally reduce the RMSPE.

\section{DISCUSSION}

The range of the measured variables in the 4 experiments that constituted the data set of our study allowed for the development and validation of different models for HDMI estimation under GA (GA1-GA10), WSB (WSB1-WSB10), GAwRW, and WSBwRW.

\section{HDMI Estimation Using the n-Alkane Method}

Herbage DMI estimated with the n-alkane method was used as the reference for model development and validation. In earlier investigations with barn-fed dairy cows, compared with the weighed intake, DMI estimation using the n-alkane method showed a low mean deviation of $0.05 \mathrm{~kg}$, and the estimated and weighed DMI were highly correlated $\left(\mathrm{R}^{2}=0.93\right)$ for pooled samples (Berry et al., 2000). In conditions that were similar to those in our study, Kaufmann et al. (2011) found a mean deviation between estimated and weighed DMI of $0.2 \mathrm{~kg}$ for cows fed in the barn with fresh herbage. No exact reference for the daily HDMI for individual animals exists under grazing conditions; thus, a genuine

Table 6. Evaluated linear model WSB8 for herbage DMI estimation for use under the approach without knowledge of the supplements fed

\begin{tabular}{|c|c|c|c|c|c|c|}
\hline \multirow[b]{2}{*}{ Item } & \multirow[b]{2}{*}{ Coefficient } & \multirow[b]{2}{*}{$\mathrm{SE}$} & \multirow[b]{2}{*}{$\beta^{1}$} & \multicolumn{2}{|c|}{$95 \% \mathrm{CI}$} & \multirow[b]{2}{*}{$P$-value } \\
\hline & & & & Lower & Upper & \\
\hline Model mean $\mu$ & -1.01 & 7.730 & 0 & -16.3488 & 14.3387 & 0.897 \\
\hline Milk lactose (\%) & -3.18 & 0.868 & -0.236 & -4.9019 & -1.4573 & $<0.001$ \\
\hline Lactation number & -0.30 & 0.115 & -0.199 & -0.5278 & -0.0701 & 0.011 \\
\hline Herbage CP (g/kg of DM) & -0.02 & 0.007 & -0.209 & -0.0353 & 0.0070 & 0.003 \\
\hline Total eating chews ${ }^{2}$ (no./d) & -0.0003 & 0.00007 & -0.488 & -0.0005 & -0.0002 & $<0.001$ \\
\hline Total eating time ${ }^{3}(\mathrm{~min} / \mathrm{d})$ & 0.03 & 0.005 & 0.636 & 0.0186 & 0.039 & $<0.001$ \\
\hline Prehension bites ${ }^{2}$ (no./d) & -0.0009 & 0.00027 & -1.994 & -0.0014 & -0.0003 & 0.002 \\
\hline Prehension bites $^{3}$ (no./d) & 0.001 & 0.00027 & 2.475 & 0.0005 & 0.0016 & $<0.001$ \\
\hline Milk protein (\%) & 1.78 & 0.712 & 0.172 & 0.3683 & 3.1930 & 0.014 \\
\hline Herbage ash (g/kg of DM) & 0.10 & 0.034 & 0.236 & 0.0331 & 0.1667 & 0.004 \\
\hline Milk yield $(\mathrm{kg} / \mathrm{d})$ & 0.13 & 0.045 & 0.216 & 0.0442 & 0.2236 & 0.004 \\
\hline BW (kg) & 0.01 & 0.004 & 0.265 & 0.0052 & 0.0197 & 0.001 \\
\hline
\end{tabular}

${ }^{1}$ Standardized coefficient; helps classify the variables according to their effect on the corresponding herbage DMI estimation model.

${ }^{2}$ Performed at pasture and in the barn.

${ }^{3}$ Performed at pasture. 
ROMBACH ET AL.

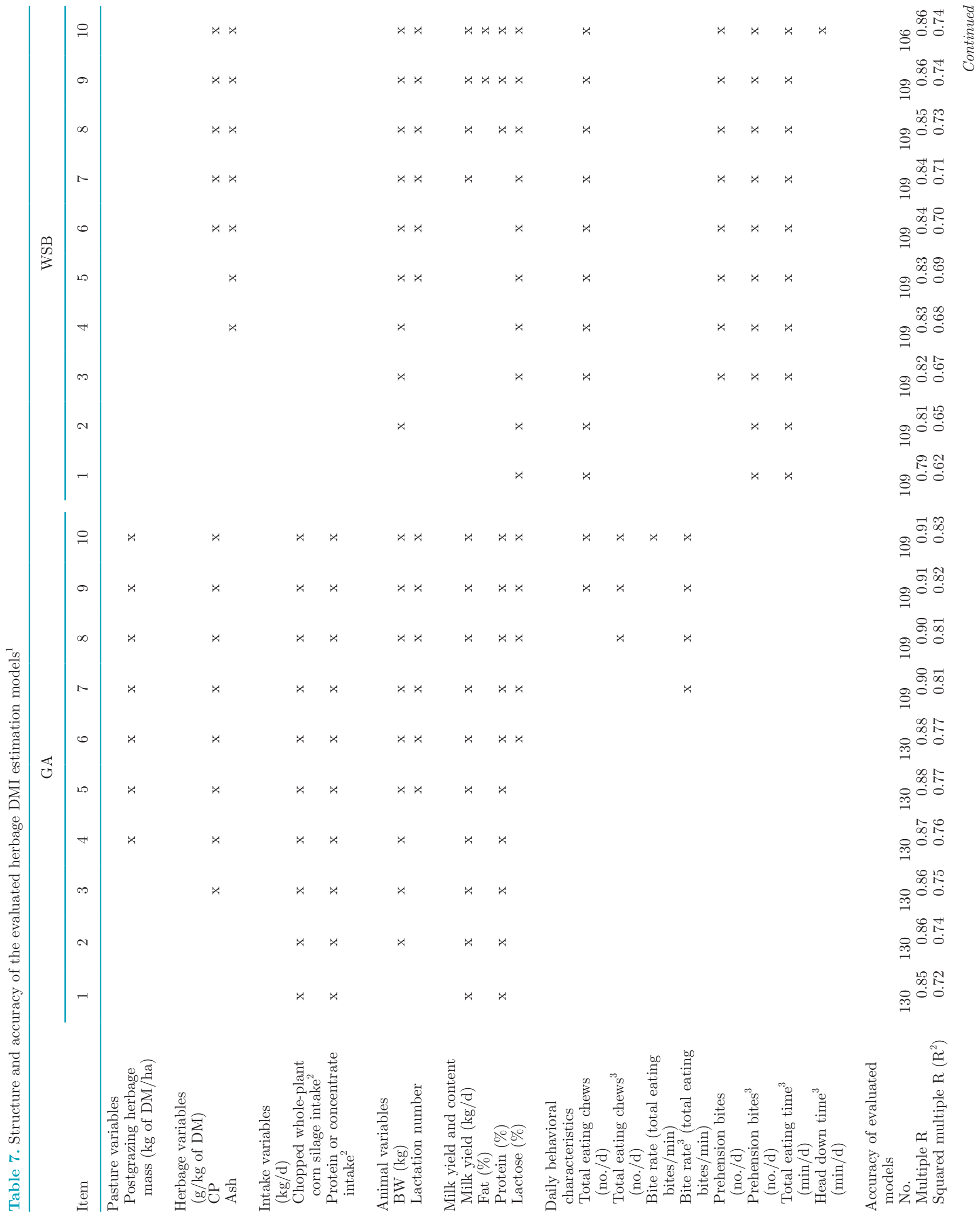




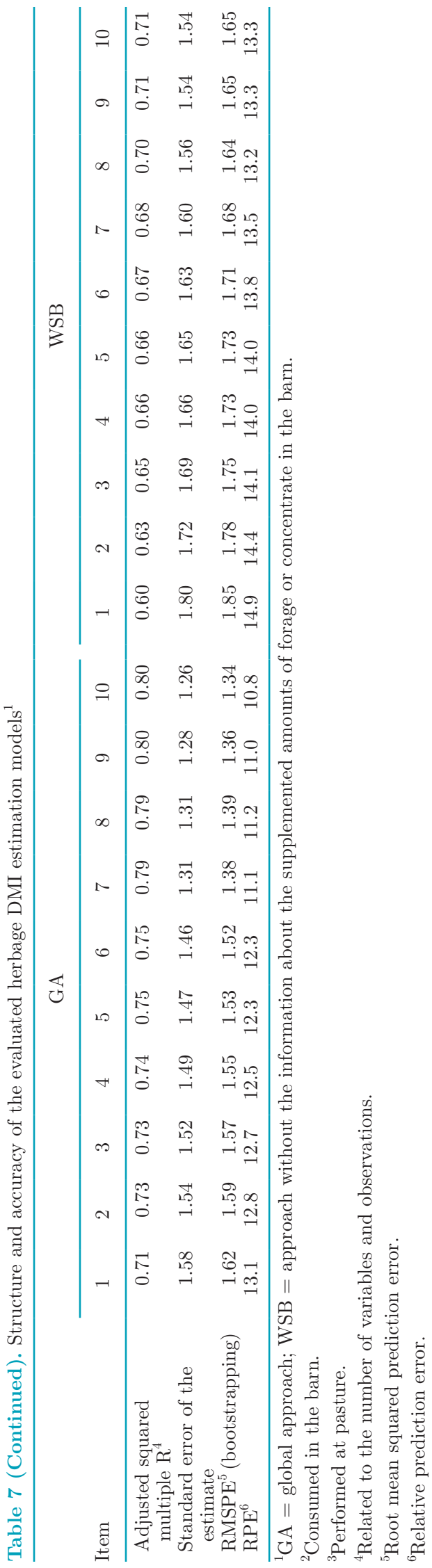

validation of the n-alkane method is not possible. Nevertheless, the n-alkane method is commonly suggested as one of the best available techniques for individual HDMI estimation of grazing animals (Smit et al., 2005; Decruyenaere et al., 2009; Pérez-Ramírez et al., 2012). However, there are weak points that may impede an accurate HDMI estimation. Lippke (2002) mentioned the diurnal variation of the n-alkane concentration in feces as one possible source of variation. To prevent variations, we administered HC32 on an apple pomace carrier twice daily. A further challenge was the collection of a representative sample of the herbage eaten by the grazing dairy cows during the day, especially in multispecies swards. Grazing cows can select for certain plant groups and graze on layers that may contain different alkane concentrations (Dove and Mayes, 2005; Heublein et al., 2017). To minimize this risk, we took herbage samples twice daily by imitating the feed selection of almost each experimental cow on pasture and pooled these. To prevent varying alkane dosing, as mentioned by Smit et al. (2005), HC32 was not applied on feeds or concentrates; instead, capsules containing the exact intended amount of HC32 were administered twice daily with a bolus gun.

Comparing our HDMI results generated with the nalkane method $[11.9 \pm 3.31(\mathrm{SD}) \mathrm{kg}$ of HDMI], the reference method, with those obtained from estimation equations for grazing dairy cows proposed by Faverdin et al. (2007) using our data set $[13.3 \pm 3.72$ (SD) $\mathrm{kg}$ of HDMI], an $\mathrm{R}^{2}$ of $0.77(\mathrm{y}=1.178+0.962 \mathrm{x}$; standard error of estimate $=1.76$ ) was obtained (Figure 2$)$. This suggests an acceptable correlation and general accordance of our reference method for HDMI, as no genuine or much better method exists.

\section{Variables Used for HDMI Estimation Models}

Behavioral characteristics are useful for HDMI estimation in many cases, although the comparison of RMSPE of the GA and GAwRW models showed no improvement in accuracy of the HDMI estimation. The importance of behavioral characteristics for HDMI estimation is shown under an approach without knowledge of the supplements fed because total eating chews, total eating time performed at pasture, prehension bites performed on pasture, and total prehension bites represent the most important variables in the WSB models. Compared with the WSBwRW models, WSB models had a lower RMSPE on average by $0.58 \mathrm{~kg} /$ cow per day. Clearly, behavioral characteristics seem to improve the accuracy of HDMI estimation if information about the amount of supplements fed in the barn to pasture is lacking. 


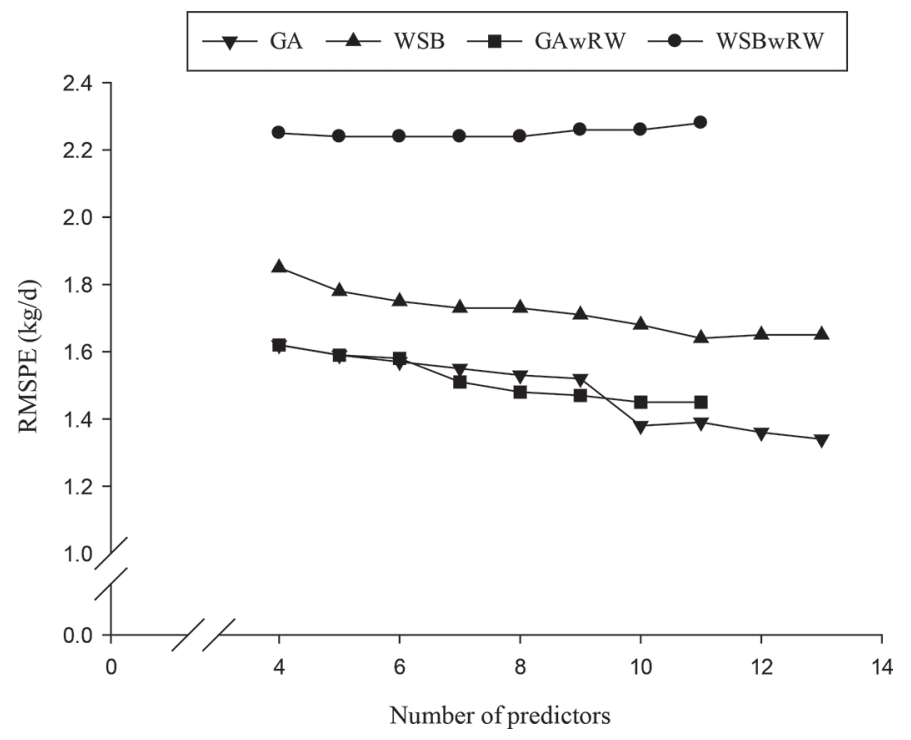

Figure 1. Comparison between the root mean squared prediction error (RMSPE) of the herbage DMI estimation models with or without behavioral characteristics in the data set for model development. GA = global approach; WSB = approach without the information about the supplemented amounts of forage or concentrate in the barn; GAwRW = GA without RumiWatch (Itin and Hoch $\mathrm{GmbH}$ Liestal, Switzerland) system variables; WSBwRW = WSB without RumiWatch system variables.

Chacon et al. (1976) already concluded that herbage intake of grazing cattle can be estimated with reasonable precision using eating bites and bite size based on esophageal fistula samples. The challenge would be to know the bite size with intact animals. Later, Halachmi et al. (2016) investigated the effect of behavioral characteristics in DMI models for intact, TMR-fed cows housed in open, no-stall cowsheds. They found an improvement of $1.3 \mathrm{~kg} / \mathrm{cow}$ per day on RMSPE,

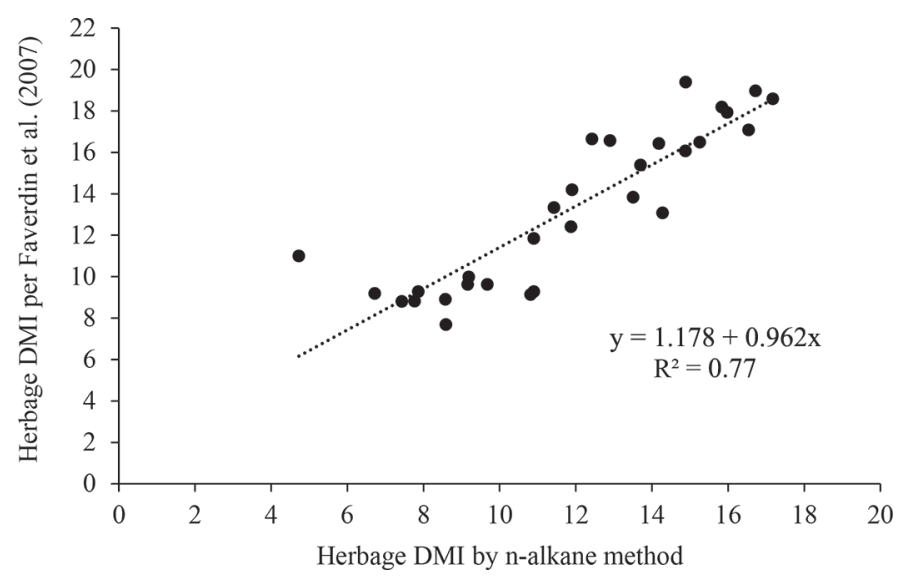

Figure 2. Comparison of our herbage DMI results generated with the n-alkane method and those obtained from estimation equations proposed by Faverdin et al. $(2007 ; \mathrm{n}=30)$. even greater than that in our study, when behavioral characteristics were incorporated in a DMI estimation model. Additional benefits of including behavioral characteristics in an intake estimation model might be the detection of sick or injured cows as well as cows in heat, as short-term feeding behavior is modified in characteristic ways in such cases (González et al., 2008). Andriamandroso et al. (2016) advocated the potential use of behavioral characteristics for HDMI estimation, as the bite is the elementary and indivisible unit of the whole grazing process. This is also seen in the present study, as according to $\beta$ the variables prehension bites performed at pasture and total prehension bites were the 2 most important variables for the WSB models. An explanation for opposite effects of prehension bites performed at pasture and total prehension bites on HDMI might be the effect of supplements fed in the barn on HDMI (substitution of herbage); this also applies to the contrasting effects of total eating chews and total eating time at pasture.

Although behavioral characteristics represent the most important variables in the WSB model, a large variation in bite mass exists among animals, grazing, pasture, and feeding managements. Stated values range between 0.33 and $0.74 \mathrm{~g}$ of $\mathrm{DM} /$ bite (Barrett et al., 2001; Penning and Rutter, 2004). This leads to an insufficient correlation between behavioral characteristics and HDMI. According to Hellwing et al. (2015), grazing activity displays a close correlation with the predicted intake, yet further characteristics may have an influence on herbage intake. Therefore, in addition to behavioral data, animal, feed, grazing, and environmental variables must be included to reduce the estimation error of HDMI estimation models.

In our study, postgrazing herbage mass $(222 \mathrm{~kg}$ of $\mathrm{DM} / \mathrm{ha}$; minimum: $63 \mathrm{~kg}$ of DM/ha; maximum: $554 \mathrm{~kg}$ of DM/ha) had a negative effect $(-0.004 \mathrm{~kg}$ of $\mathrm{DMI} / \mathrm{d}$ per kg of DM per ha) on HDMI. Contradicting results were found by O'Neill et al. (2013) with no or a positive effect of postgrazing sward height up to $0.99 \mathrm{~kg}$ of $\mathrm{DMI} / \mathrm{cm}$ per day. As postgrazing sward height or postgrazing herbage mass are a function of pregrazing herbage mass and daily herbage allowance, differences in these factors as well as their interaction might have been partly the source of the contrasting results. Also, herbage CP content showed a negative effect on HDMI. This contradicts the findings of Timmer et al. (2016), who found a positive effect of milk urea content, which is associated with the intake of either $\mathrm{CP}$ or ruminally degraded CP. Results similar to those of Timmer et al. (2016) were found for milk protein content; thus, a higher HDMI is correlated with a higher milk protein content. Timmer et al. (2016) likewise found an effect of $3.79 \mathrm{~kg}$ of DMI/\% of milk protein per day. The par- 
tially contradicting and partially similar results of our models and those of Timmer et al. (2016) might be caused by the interactions between the variables used, as discussed by Gruber et al. (2005).

Amounts of concentrate and protein supplement were merged into a single variable because the substitution rates are similar and lower than those for a forage supplement (chopped whole-plant corn silage; Delagarde and O'Donovan, 2005). The feeding of protein and concentrate supplements was associated with a decrease of HDMI in the GA model. O'Neill et al. (2013) observed a substitution rate of 0.58 to $0.71 \mathrm{~kg}$ of HDMI $/ \mathrm{kg}$ of concentrate compared with our results (0.63 kg of HDMI $/ \mathrm{kg}$ of concentrate). An even smaller reduction of $0.36 \mathrm{~kg}$ of $\mathrm{HDMI} / \mathrm{kg}$ of concentrate was found for early-lactation dairy cows (McEvoy et al., 2009). The greater substitution rate in our studies could have been the result of a generous herbage allowance (Penno et al., 2006) in most of our studies. Thus, previous studies showed a substitution rate of zero for a high grazing pressure up to 0.6 to 0.8 for a low grazing pressure (Stockdale, 2000; Peyraud et al., 2001). Besides the generous herbage allowance, an increased amount of supplemented feed (Penno et al., 2006) or lactation stage could have had an influence; thus, cows in early lactation showed a lower substitution rate compared with cows in mid or late lactation (Penno et al., 2006). Furthermore, the substitution rate is greater when the quality of pasture allows cows to attain greater DMI from pasture alone (Penno et al., 2006).

Other reasons for the high substitution rate might be that the interaction between variables used in the models affected the coefficients, as discussed by Gruber et al. (2005), and maybe some bias due to different conditions between experiments. For example, the average of the calculated substitution rate between supplemented and not-supplemented pairs within experiments $[0.63$ $\pm 0.015(\mathrm{SD}) \mathrm{kg}$ of HDMI $/ \mathrm{kg}$ of concentrate or protein supplement] was lower compared with the coefficient of the explanatory variable protein and concentrate supplements (1.09 kg of DM/d) in GA7. The calculated substitution rate is similar to the findings of Stockdale (2000) and Peyraud et al. (2001). The decrease in HDMI caused by the supplementation of chopped whole-plant corn silage was smaller compared with that found for concentrate and protein supplementation. However, the coefficients $(0.64 \mathrm{~kg}$ of $\mathrm{DM} / \mathrm{d})$ in this case are comparable with the calculated substitution rate $[0.47 \pm$ 0.015 (SD) $\mathrm{kg}$ of HDMI $/ \mathrm{kg}$ of chopped whole-plant corn silage supplement]. Usually, substitution rates resulting from supplementing forage to pasture are greater than those from supplementing concentrates due to the greater forage fill (unité d'encombrement; Faverdin et al., 2007) value representing rumen fill (Delagarde and
O'Donovan, 2005). Different experiments were used to calculate substitution rates. Varying environmental, feed, and animal characteristics may have therefore caused inconsistent substitution rates between concentrates and forage even though the individual substitution rates were in an expected range.

As a measure for body size and an indicator for rumen size, BW was positively correlated with HDMI in our study (i.e., an increase of 0.8 to $1 \mathrm{~kg} / 100 \mathrm{~kg}$ of BW for our models). Similar increases of 0.95 and $1.3 \mathrm{~kg} / 100$ $\mathrm{kg}$ of BW were measured by Delagarde and O'Donovan (2005) and Gruber et al. (2005). A considerably greater increase in grass DMI, $2.0 \mathrm{~kg} / 100 \mathrm{~kg}$ of BW (McEvoy et al., 2009), may be related to the early lactation stage of their cows compared with our study. Gruber et al. (2005) showed a greater increase in DMI per $100 \mathrm{~kg}$ of BW for cows in early lactation compared with cows in mid or late lactation.

Besides the physical feed intake capacity of the cow, proxied by BW, total DMI seems to be one driving force for milk production and vice versa, a conclusion that has been drawn in several other studies (Delagarde and O'Donovan, 2005; Gruber et al., 2005; McEvoy et al., 2009). The coefficient of the explanatory variable milk yield was between 0.13 (WSB8) and 0.35 (GA7) $\mathrm{kg}$ of $\mathrm{HDMI} / \mathrm{kg}$ of milk per day. A reason for differences in the coefficients for milk yield between GA7 and WSB8 might be the aforementioned interaction between the variables used in the models.

\section{Precision of the HDMI Estimation Models}

The models GA7 and WSB8 showed the highest accuracy in estimating HDMI, with an $\mathrm{R}^{2}$ of 0.81 and 0.73 and an RPE of 11.1 and $13.2 \%$, respectively. The explained proportion of variation of the HDMI and the accuracy of these models are similar to those of other investigations. The models of McEvoy et al. (2009) accounted for $79 \%$ of the HDMI variation for earlylactating dairy cows, and those of Timmer et al. (2016) accounted for $84 \%$ of the HDMI variation. Delagarde and O'Donovan (2005) obtained an RPE between 10 and $25 \%$ for the HDMI of grazing dairy cows. Likewise, Keady et al. (2004) found an RPE for grass silage DMI between 10 and $20 \%$ for dairy cows fed indoors. Overall, the RPE of all of our models, developed for use under GA (RPE $=10.8-13.1 \%)$ as well as under WSB $(\mathrm{RPE}=13.3-14.9 \%)$, showed an acceptable prediction of HDMI using detectable variables. Fuentes-Pila et al. (1996) suggested that an RPE value lower than $10 \%$ indicates a satisfactory prediction of the DMI, whereas an RPE between 10 and $20 \%$ indicates a relatively good or acceptable prediction, and an RPE greater than $20 \%$ indicates an unsatisfactory prediction. According to 
Delagarde et al. (2011), a threshold for good intake estimation models for practical use should be a mean prediction error of $10 \%$. Nevertheless, this threshold is hard to achieve, particularly for grazing dairy cows, as the available reference methods for development and validation of the HDMI estimation models are indirect methods. Furthermore, Galyean (2016) argued that daily intake of cattle is naturally variable, and Gruber et al. (2005) stated that a biologically determined natural scattering of about $10 \%$ might also impede the development of reliable intake estimation models.

\section{CONCLUSIONS}

With the HDMI estimation models developed in this study, HDMI could be estimated with an RPE between $11.1 \%$ (GA7) and $13.2 \%$ (WSB8) at best. When the amount of supplements fed was unknown, the inclusion of behavioral characteristics in the model showed a clear added value regarding the accuracy of the individual HDMI estimation. On the other hand, the inclusion of behavioral characteristics in the HDMI estimation model when amount of supplements fed was known did not significantly reduce the RMSPE. Finally, a larger data set (in terms of number of animals and herds and covering more breeds, different grazing systems, and management patterns, including, for example, varying supplementation) will be needed for further development and validation of a robust HDMI estimation model.

\section{REFERENCES}

Agroscope. 2006. Fütterungsempfehlungen und Nährwerttabellen für Wiederkäuer (Feeding recommendations and nutrient tables for ruminants). Accessed Sep. 8, 2014. http://www.agroscope.admin .ch/futtermitteldatenbank/04834/index.html?lang=de.

Agroscope. 2015. Fütterungsempfehlungen und Nährwerttabellen für Wiederkäuer (Feeding recommendations and nutrient tables for ruminants). Accessed Oct. 6, 2015. http://www.agroscope.admin .ch/futtermitteldatenbank/04834/index.html?lang=de.

Andriamandroso, A. L. H., J. Bindelle, B. Mercatoris, and F. Lebeau. 2016. A review on the use of sensors to monitor cattle jaw movements and behavior when grazing. Biotechnol. Agron. Soc. Environ. 20(Suppl. 1):273-286

AOAC International. 1995. Official Methods of Analysis. 16th ed. AOAC International, Arlington, VA.

Arnott, G., C. Ferris, and N. O'Connell. 2017. Review: Welfare of dairy cows in continuously housed and pasture-based production systems. Animal 11:261-273.

Barrett, P. D., A. S. Laidlaw, C. S. Mayne, and H. Christie. 2001. Pattern of herbage intake rate and bite dimensions of rotationally grazed dairy cows as sward height declines. Grass Forage Sci. 56:362-373.

Berry, N. R., M. R. Scheeder, F. Sutter, T. F. Kröber, and M. Kreuzer. 2000. The accuracy of intake estimation based on the use of alkane controlled-release capsules and faeces grab sampling in cows. Ann. Zootech. 49:3-13.

Chacon, E., T. H. Stobbs, and R. L. Sandland. 1976. Estimation of herbage consumption by grazing cattle using measurements of eating behaviour. Grass Forage Sci. 31:81-87.
Decruyenaere, V., A. Buldgen, and D. Stilmant. 2009. Factors affecting intake by grazing ruminants and related quantification methods: A review. Biotechnol. Agron. Soc. Environ. 13:559-573.

Delagarde, R., and M. O'Donovan. 2005. Modelling of herbage intake and milk production by grazing dairy cows. Pages 89-104 in Utilisation of Grazed Grass in Temperate Animal Systems: Proc. Satellite Workshop XXth International Grassland Congress, Cork, Ireland. J. J. Murphy, ed. Wageningen Academic Publishers, Wageningen, the Netherlands.

Delagarde, R., H. Valk, C. S. Mayne, A. J. Rook, A. González-Rodríguez, C. Baratte, P. Faverdin, and J. L. Peyraud. 2011. GrazeIn: A model of herbage intake and milk production for grazing dairy cows. 3. Simulations and external validation of the model. Grass Forage Sci. 66:61-77.

Dove, H., and R. W. Mayes. 2005. Using n-alkanes and other plant wax components to estimate intake, digestibility and diet composition of grazing/browsing sheep and goats. Small Rumin. Res. 59:123-139.

Efron, B., and T. Hastie. 2016. The jackknife and the bootstrap and bootstrap confidence intervals. Pages 155-204 in Computer Age Statistical Inference. B. Efron and T. Hastie, ed. Cambridge University Press, Cambridge, UK.

Faverdin, P., R. Delagarde, L. Delaby, and F. Meschy. 2007. Alimentation des vaches laitieres. Pages 23-57 in Alimentation des Bovins, Ovins et Caprins: Besoins des Animaux-Valeur des Aliments. Editions Quae, Versailles Cedex, France.

Fox, J. 2005. The R Commander: A basic statistics graphical user interface to R. J. Stat. Softw. 14:1-42.

Fox, J. 2017. Using the R Commander: A Point-and-Click Interface for R. CRC Press, Boca Raton, FL.

Fox, J., and M. Bouchet-Valat. 2017. Rcmdr: R Commander. R package version 2.3-2. Accessed Jul. 7, 2016. https://CRAN.R-project .org $/$ package $=$ rms.

Fuentes-Pila, J., M. DeLorenzo, D. Beede, C. Staples, and J. Holter. 1996. Evaluation of equations based on animal factors to predict intake of lactating Holstein cows. J. Dairy Sci. 79:1562-1571.

Galyean, M. 2016. Predicting forage intake in extensive grazing systems. J. Anim. Sci. 94:26-43.

Getter, K. L., B. K. Behe, P. H. Howard, D. S. Conner, and L. M. Spaniolo. 2015. Increasing demand for pasture-based dairy: What attributes and images do consumers want? Pages 125-140 in ReThinking Organic Food and Farming in a Changing World. B Freyer and J. Bingen, ed. Springer, Berlin, Germany.

González, L. A., B. J. Tolkamp, M. P. Coffey, A. Ferret, and I. Kyriazakis. 2008. Changes in feeding behavior as possible indicators for the automatic monitoring of health disorders in dairy cows. J. Dairy Sci. 91:1017-1028.

Gruber, L., F. J. Schwarz, D. Erdin, B. Fischer, H. Spiekers, H. Steingass, U. Meyer, A. Chassot, T. Jilg, A. Omermaier, and T. Gruggenberg. 2005. Vorhersage der Futteraufnahme von Milchkühen Datenbasis von 10 Forschungs- und Universitätsinstituten Deutschlands, Österreichs and der Schweiz. 116. VDLUFA-Kongress, Rostock, Germany.

Guyader, J., H. Janzen, R. Kroebel, and K. Beauchemin. 2016. Forage use to improve environmental sustainability of ruminant production. J. Anim. Sci. 94:3147-3158.

Halachmi, I., Y. B. Meir, J. Miron, and E. Maltz. 2016. Feeding behavior improves prediction of dairy cow voluntary feed intake but cannot serve as the sole indicator. Animal 10:1501-1506.

Harrell, F. E. 2015. Regression Modeling Strategies: With Applications to Linear Models, Logistic and Ordinal Regression, and Survival Analysis. 2nd ed. Springer International, Cham, Switzerland.

Harrell, F. E. 2017. rms: Regression Modeling Strategies. R package version 5.1-0. Accessed Jul. 7, 2016. https://CRAN.R-project.org/ package $=$ rms

Hellwing, A. L. F., P. Lund, M. R. Weisbjerg, F. W. Oudshoorn, L. Munksgaard, and T. Kristensen. 2015. Comparison of methods for estimating herbage intake in grazing dairy cows. Livest. Sci. $176: 61-74$ 
Heublein, C., K.-H. Südekum, F. Gill, F. Dohme-Meier, and F. Schori. 2017. Using plant wax markers to estimate the diet composition of grazing Holstein dairy cows. J. Dairy Sci. 100:1019-1036.

Holshof, G., A. Evers, M. De Haan, and P. Galama. 2015. Grazing and difficult circumstances: Economic benefits depend on milk price and grazing efficiency. Pages 236-238 in Proc. EGF, Grassland Science in Europe, Trondheim, Norway. A. van den Pol-van Dasselaar, H. F. M. van den Aarts, A. De Vliegher, A. Elgersma, D. Reheul, J. A. Reijneveld, J. Verloop, and A. Hopkins, ed. Wageningen Academic Publishers, Wageningen, the Netherlands.

ISO (International Organization for Standardization). 2008. Food products - Determination of the total nitrogen content by combustion according to the Dumas principle and calculation of the crude protein content. Method 16634-1. ISO, Geneva, Switzerland.

ISO (International Organization for Standardization). 2009. Animal feeding stuffs - Determination of calcium, sodium, phosphorus, magnesium, potassium, iron, zinc, copper, manganese, cobalt, molybdenum, arsenic, lead and cadmium by ICP-AES. Method 27085. ISO, Geneva, Switzerland.

Kaufmann, L. D., A. Münger, M. Rérat, P. Junghans, S. Görs, C. C. Metges, and F. Dohme-Meier. 2011. Energy expenditure of grazing cows and cows fed grass indoors as determined by the $13 \mathrm{C}$ bicarbonate dilution technique using an automatic blood sampling system. J. Dairy Sci. 94:1989-2000.

Keady, T., C. Mayne, and D. Kilpatrick. 2004. An evaluation of five models commonly used to predict food intake of lactating dairy cattle. Livest. Prod. Sci. 89:129-138.

Kristensen, T., M. L. Madsen, and E. Noe. 2010. The use of grazing in intensive dairy production and assessment of farmers' attitude towards grazing. Pages 964-966 in Proc. EGF, Grassland Science in Europe, Kiel, Germany. H. Schnyder, J. Isselstein, F. Taube, K. Auerswald, J. Schellberg, M. Wachendorf, A. Herrmann, M. Gierus, N. Wrage, and A. Hopkins, ed. Mecke Druck und Verlag, Duderstadt, Germany.

Lippke, H. 2002. Estimation of forage intake by ruminants on pasture. Crop Sci. 42:869-872.

Lumley, T., and A. Miller. 2017. Leaps: Regression subset selection. $\mathrm{R}$ package version 3.0. Accessed Jan. 10, 2017. https:/CRAN.R -project.org/package=leaps.

Mayes, R. W., C. S. Lamb, and P. M. Colgrove. 1986. The use of dosed and herbage n-alkanes as markers for the determination of herbage intake. J. Agric. Sci. 107:161-170.

McEvoy, M., L. Delaby, E. Kennedy, T. Boland, and M. O'Donovan. 2009. Early lactation dairy cows: Development of equations to predict intake and milk performance at grazing. Livest. Sci. 122:214221

O'Callaghan, T. F., D. Hennessy, S. McAuliffe, K. N. Kilcawley, M. O'Donovan, P. Dillon, R. P. Ross, and C. Stanton. 2016. Effect of pasture versus indoor feeding systems on raw milk composition and quality over an entire lactation. J. Dairy Sci. 99:9424-9440.

O'Neill, B. F., E. Lewis, M. O'Donovan, L. Shalloo, N. Galvin, F. Mulligan, T. Boland, and R. Delagarde. 2013. Predicting grass dry matter intake, milk yield and milk fat and protein yield of spring calving grazing dairy cows during the grazing season. Animal 7:1379-1389.
Oudshoorn, F. W., C. Cornou, A. L. F. Hellwing, H. H. Hansen, L. Munksgaard, P. Lund, and T. Kristensen. 2013. Estimation of grass intake on pasture for dairy cows using tightly and loosely mounted di-and tri-axial accelerometers combined with bite count. Comput. Electron. Agric. 99:227-235.

Penning, P. D., and S. M. Rutter. 2004. Ingestive behaviour. Pages 1-191 in Herbage Intake Handbook. P. D. Penning, ed. British Grassland Society, Maidenhead, UK.

Penno, J., K. Macdonald, C. W. Holmes, S. Davis, G. Wilson, I. M. Brookes, and E. Thom. 2006. Responses to supplementation by dairy cows given low pasture allowances in different seasons 1. Pasture intake and substitution. Anim. Sci. 82:661-670.

Pérez-Ramírez, E., J. L. Peyraud, and R. Delagarde. 2012. N-alkanes v. ytterbium/faecal index as two methods for estimating herbage intake of dairy cows fed on diets differing in the herbage:maize silage ratio and feeding level. Animal 6:232-244.

Peyraud, J. L., L. Delaby, P. Garnsworthy, and J. Wiseman. 2001. Ideal concentrate feeds for grazing dairy cows - Responses to supplementation in interaction with grazing management and grass quality. Pages 203-220 in Recent Advances in Animal Nutrition. P. Garnsworthy and J. Wiseman, ed. Nottingham University Press, Nottingham, UK.

R Core Team. 2016. R: A Language and Environment for Statistical Computing. R Foundation for Statistical Computing, Vienna, Austria.

Rombach, M., A. Münger, J. Niederhauser, K.-H. Südekum, and F. Schori. 2018. Evaluation and validation of an automatic jaw movement recorder (RumiWatch) on unsupplemented or supplemented dairy cows on pasture. J. Dairy Sci. 101:2463-2475.

Ruuska, S., S. Kajava, M. Mughal, N. Zehner, and J. Mononen. 2016. Validation of a pressure sensor-based system for measuring eating, rumination and drinking behaviour of dairy cattle. Appl. Anim. Behav. Sci. 174:19-23.

Smit, H. J., H. Z. Taweel, B. M. Tas, S. Tamminga, and A. Elgersma. 2005. Comparison of techniques for estimating herbage intake of grazing dairy cows. J. Dairy Sci. 88:1827-1836.

Stockdale, C. 2000. Levels of pasture substitution when concentrates are fed to grazing dairy cows in northern Victoria. Anim. Prod. Sci. 40:913-921.

Thanner, S., F. Dohme-Meier, S. Görs, C. Metges, R. Bruckmaier, and F. Schori. 2014. The energy expenditure of 2 Holstein cow strains in an organic grazing system. J. Dairy Sci. 97:2789-2799.

Timmer, B., R. L. G. Zom, G. Holshof, M. Spithoven, and C. G. Van Reenen. 2016. The application of behavior sensors and sward measurement to support grazing management. Pages 80-82 in Proc. EGF, Grassland Science in Europe, Trondheim, Norway. M. Höglind, A. K. Bakken, K. A. Hovstad, E. Kallioniemi, H. Riley, H. Steinshamn, and L. Østrem, ed. Wageningen Academic Publishers, Wageningen, the Netherlands.

Van den Pol, A., A. de Vliegher, D. Hennessy, J. Isselstein, and J. Peyraud. 2015. The future of grazing. Accessed May 10, 2017. https:/ /www.europeangrassland.org/. 